\title{
Long-Term Cardiovascular Effects of Pregnancy-Related Disorders
}

\author{
Jyotsna Maddury Kumar Achukatla² \\ ${ }^{1}$ Nizams Institute of Medical Sciences, Punjagutta, Hyderabad, India \\ 2Department of Cardiology, Nizam's Institute of Medical Sciences, \\ Punjagutta, Hyderabad, India
}

Address for correspondence Jyotsna Maddury, MD, DM, Nizam's Institute of Medical Sciences, Punjagutta, 500082, Hyderabad, India (e-mail: mail2jyotsna@rediffmail.com).

\begin{abstract}
Keywords

- cardiovascular effects

- gestational diabetes

- preeclampsia

- pregnancy

Usually, pregnancy-elated effects and changes in the different organs terminate after delivery or maybe within 6 months. Long-term effect of complicated pregnancies leading to long-term cardiovascular and other diseases was recognized long back. With the accumulating evidence with many landmark studies, it became mandatory to have pregnancy heart team approach not only to manage during pregnancy and peripartum period but also to monitor future events and educate the pregnant women about the modification of cardiovascular risks for prevention of anticipated events. In this review, more importance is given to risk-stratify these women with complicated pregnancy and recommendation to prevent the long-term effects.
\end{abstract}

\section{Introduction}

The changes that occur during pregnancy are expected to terminate their effect after delivery, which sometimes may extend up to 6 weeks after delivery, for example preeclampsia, gestational diabetics, etc. Much was discussed on recurrence of some diseases such as preterm labor or preeclampsia that have greater chances of recurrence in subsequent pregnancies. However, in the recent past, it was realized that the events that occurred during pregnancy predicted the development of future events in the life. ${ }^{1}$

Similarly, it is well known that obstetric complications are related to long-term complications of the newborn. However, Pariente et al and Almasi et al showed that the small for gestational baby birth was the predictor for maternal cardiovascular disease (CVD) later in the life. ${ }^{2,3}$ In the mother, the cause of the long-term effects of the pregnancy was debated by many researchers. Some authors suggest that the longterm effects may not be due to the pregnancy as such, but it may be due to the expression of already existing predisposing factors during pregnancy. In addition, some authors say that pregnancy acts as a long term stress ( 9 months) that may have effects on the long-term maternal health. ${ }^{4}$
In this review article, the authors discussed the different pregnancy-related problems with their pathophysiology, which may be responsible for long-term effect on the cardiovascular system of the mother with evidence of previous studies.

\section{Gestational Diabetes}

Glucose tolerance test was performed on the patients who had the previous history of gestational diabetes by giving $75 \mathrm{~g}$ of glucose 6 to 12 weeks after delivery. Approximately 2 to $16 \%$ patients were detected to be type 2 diabetic, and $36 \%$ of patients had an intolerance to carbohydrates. Therefore, nearly 36 to $70 \%$ of GDM (gestational diabetes mellitus) women were prone to type 2 diabetes in the long run $^{1}(-$ Fig. 1 ) and GDM

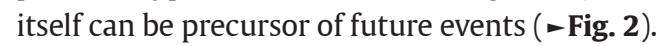

Studies that concentrated on the subsequent development of type 2 diabetes mellitus (DM) and another cardiovascular morbidity in GDM women are mentioned in - Table 1. ${ }^{5-11}$

As prevention is better than cure, the American College of Obstetricians and Gynaecologists (ACOG) joined a program "Call for Action" that is an initiative of the National Diabetes Education to provide better health outcomes of women with prior GDM and their children ${ }^{12}$ ( - Fig. 3 ). 


\section{Preeclampsia}

Preeclampsia induces micro-angiopathy that affects both the mother and fetus ( - Fig.4). These changes of micro-angiopathy on the different organs do not dissolve after index pregnancy, which may be responsible for future maternal cardiovascular events ( - Fig. 5). The severity of development of long-term cardiovascular morbidity in the mother depends not only on having preeclampsia during pregnancy but also on how early it appears, birth weight of the baby, etc. ( - Fig. 6). The relative risk of future events in eclampsia and preeclamptic mothers is represented in - Fig. 7. ${ }^{13,14} \mathrm{In}$ fact, gestational hypertension in the other futures of preeclampsia can also give rise in myocardial ischemia later in the life.

The long-term effects of preeclampsia in a mother are not only for the risk of hypertension but also for stroke, ischemic heart disease, venous thromboembolism, and overall mortality in the future ( - Fig. 8).

The fact that eclampsia can lead to late cardiovascular events are substantiated by multiple studies ( $\mathbf{- T a b l e ~ 2 ) .}{ }^{15-23}$

Few authors suggested that as early preeclampsia is associated with subsequent development of significant events, it is worth starting the preventive measures immediately after delivery. Few studies have concentrated on another cardiovascular risk (CVR) in preeclamptic women, which are mentioned in - Table 3 . $^{24-27}$

Studies mentioned in $\mathbf{- T a b l e} \mathbf{4}$ proved that preeclampsia increases not only CVR but other organ system disorders also. ${ }^{28-31}$

\section{Pathophysiology of Preeclampsia Leading to Cardiovascular Risk}

There are a few common factors for both preeclampsia and CVD. Because of this common association, these preeclamptic patients develop CVD subsequently ( - Fig. 9). ${ }^{32}$

The main mechanism of preeclampsia leading to CVR later in the life is due to the endothelial dysfunction induced during pregnancy ( - Fig. 10). ${ }^{23}$

\section{Preterm Deliveries}

Preterm births were categorized as late (35-36 weeks), moderate (33-34 weeks), or extreme ( $\leq 32$ weeks), and as spontaneous or indicated. In the previous section of preeclampsia, the effect of preterm delivery and of low-birthweight baby was discussed. Preterm delivery with preeclampsia also has the risk of having a cardiac event later in the life. Studies supporting this are mentioned in - Table 5..$^{2,33-36}$

\section{Placental Abruption}

Placental abruption is a condition with microvascular disturbance and leads to long-term effects on the mother's health. The type of future cardiac diseases predisposed by placental abruption is mentioned in - Fig. 11. In - Table $6{ }^{37-40}$ studies on placental abruption are mentioned.

\section{Stillbirth and Recurrent Miscarriages}

A recurrent miscarriage in the mother is an indication to check for collagen vascular disorders. However, Pariente et al and Kessous et al have shown that recurrent miscarriages and stillbirths in women will predict the future cardiovascular events $^{41,42}$ (-Table 7).

\section{Maternal Obesity during Pregnancy}

Maternal obesity during pregnancy will lead to obesity and related complications later in life. Reduction of even a few kilograms in weight, even for a shorter duration, has good long-term effects. Sasson et al concluded that obesity during pregnancy is an independent risk factor for long-term ophthalmic complications such as diabetic retinopathy. ${ }^{43}$ According to the 2016 Action for Health in Diabetes Study Group reports, weight loss in the overweight/obese individuals with type 2 diabetes had significant improvements in hemoglobin $\mathrm{A}_{1 \mathrm{C}}\left(\mathrm{HbA}_{1 \mathrm{C}}\right)$, systolic blood pressure, high-density lipoprotein (HDL) cholesterol, and triglycerides $(p \leq 0.02) .{ }^{44}$

\section{Women with Small for Gestational Age Neonate}

Delivery of a small for gestational age (SGA) infant was one of the risk factors for the future maternal health. Parient et $\mathrm{al}^{45}$ and Almasi et $\mathrm{al}^{3}$ state that the delivery of an SGA neonate may lead to long-term complex cardiovascular events, including congestive heart failure, hypertensive heart and kidney disease, and acute cor pulmonale (odds ratio $[\mathrm{OR}]=2.3 ; 95 \%$ confidence interval $[\mathrm{CI}]: 1.3-4.4$; $p=0.006)$, and also long-term cardiovascular mortality ( $\mathrm{OR}=3.4 ; 95 \% \mathrm{CI}: 1.5-7.6 ; p=0.006)$.

\section{Miscellaneous}

1. Transient hypothyroidism in pregnancy can antedate CVD in later age.

2. Peripartum cardiomyopathy-the detailed discussion was given in a separate review (See Heart Failure in Pregnancy, p. 161 this issue).

- Table 8 shows the diseases during pregnancy and their later development of cardiovascular and other organ involvements. ${ }^{46,47}$

\section{Preventive Measures}

As many women come to regular checkup during pregnancy, it is an ideal time to detect the women who are at risk for the future CVD and implement at the same time the primary 
preventive strategies early such as health monitoring, lifestyle modifications, and other interventions, that will help reduce the burden of CVD ( - Fig. 12). ${ }^{48}$

Even though many obstetricians and gynecologists are aware of the fact that the risk of CVDs after preeclampsia is high, during the follow-up these women are not counseled and informed for preventive measures. By the implementation of the current guidelines both by obstetrician and cardiologists, these deficiencies can be overcome. ${ }^{49}$

\section{Conclusion}

In women with a moderate or high risk of complications during pregnancy (modified World Health Organization [mWHO] II-III, III, and IV), prepregnancy counseling and management during and around delivery should be performed in an expert center by a multidisciplinary tea the pregnancy heart team. ${ }^{50}$ Follow them subsequently annually along with modification of CVR.

\section{Tables and Figures}

Table 1 Studies showing the increase in latter development of DM and CV morbidity in GDM women

\begin{tabular}{|c|c|c|c|}
\hline Study author & Year & Inclusion no. & Results \\
\hline Lauenborg et al & 2005 & $\begin{array}{l}\text { 9.8-y follow-up-481 } \\
\text { Danish women; prior } \\
\text { diet-treated GDM after } \\
\text { pregnancy }\end{array}$ & $\begin{array}{l}\text { Metabolic syndrome: } \\
\text { 1. Prior diet-treated GDM 3-fold > age-matched } \\
\text { control patients }(p<0.0005) \text {. } \\
\text { 2. Obese women (BMI > 30) with previous GDM } \\
\text { 7-fold }>\text { normal-weight prior GDM women } \\
(\text { BMI }<25) \\
\text { 3. Prevalence-glucose tolerant GDM group }>2 \\
\text { times control group }\end{array}$ \\
\hline Bellamy et al & 2009 & $\begin{array}{l}\text { Comprehensive } \\
\text { systematic review and } \\
\text { meta-analysis }\end{array}$ & Gestational diabetes $\leftrightarrow$ risk of type 2 diabetes \\
\hline Göbl et al & 2011 & $10-y$ study & $\begin{array}{l}\text { Glucose tolerance-impaired in GD predictors of } \\
\text { DM after GDM, HDL cholesterol }<50 \mathrm{mg} / \mathrm{dL} \text { and } \\
\text { age }(>35 \mathrm{y})\end{array}$ \\
\hline Lee et al & 2012 & $\begin{array}{l}15 \text { prospective } \\
\text { studies-760,925 } \\
\text { participants }\end{array}$ & $\begin{array}{l}\text { Prediabetes- }-\uparrow \text { stroke-impairment of glucose } \\
\text { tolerance/combination of impaired fasting } \\
\text { glucose and glucose tolerance }\end{array}$ \\
\hline Kessous et al & 2013 & $\begin{array}{l}47,909 \\
10-y \text { follow-up }\end{array}$ & $\begin{array}{l}4,928(10.3 \%) \text { GDM- } \uparrow \text { rate of CV morbidity- } \\
\text { noninvasive cardiac diagnostic procedures } \\
(\mathrm{OR}=1.8 ; 95 \% \mathrm{Cl}: 1.4-2.2) \text {, simple CV events } \\
(\mathrm{OR}=2.7 ; 95 \% \mathrm{Cl}: 2.4-3.1) \text {, and total CV } \\
\text { hospitalizations (OR }=2.3 ; 95 \% \mathrm{Cl}: 2.0-2.5)\end{array}$ \\
\hline Valizadeh et al & 2015 & $\begin{array}{l}110 \text { women-abnormal } \\
\text { glucose levels and } \\
\text { metabolic syndrome; } \\
1-6 \text { y prior GD }\end{array}$ & $\begin{array}{l}36 \text { (32.7\%)-type2 DM, } 11 \text { (10\%)-impaired } \\
\text { fasting glucose or impaired glucose tolerance, } \\
\text { and } 22(20 \%) \text {-metabolic syndrome }\end{array}$ \\
\hline Huang et al & 2016 & $\begin{array}{l}\text { Meta-analysis and } \\
\text { prospective cohort }\end{array}$ & $\begin{array}{l}\text { Prediabetes- } \uparrow \text { CVD/CHD and mortality: } \\
\text { impairment-glucose tolerance, fasting glucose } \\
<5.6 \mathrm{mmol} / \mathrm{L} / \mathrm{HbA}{ }_{1 C}(39 \mathrm{mmol} / \mathrm{mol}) \text { and } \uparrow \mathrm{HbA}_{1 \mathrm{C}} \\
(39-7 \mathrm{mmol} / \mathrm{mol})\end{array}$ \\
\hline
\end{tabular}

Abbreviations: BMI, body mass index; $\mathrm{Cl}$, confidence interval; CV, cardiovascular; CVD, cardiovascular disease; CHD, coronary heart disease; DM, diabetes mellitus; GD, gestational diabetes; GDM, gestational diabetes mellitus; $\mathrm{HbA}_{1 C}$, hemoglobin $\mathrm{A}_{1 \mathrm{C}}$; $\mathrm{HDL}$, high-density lipoprotein; OR, odds ratio. 
Table 2 Studies showing the increase in late CV morbidity in preeclamptic women

\begin{tabular}{|c|c|c|}
\hline Study author & Year & Results \\
\hline McDonald et al & 2013 & $\begin{array}{l}\text { Women with a history of severe preeclampsia had higher rates of previous CVD than } \\
\text { women with nonsevere preeclampsia or women without preeclampsia ( } 87,72 \text {, and } 72 \% \text {, } \\
p=0.0019) \text {. Even after accounting for CV risk factors including albuminuria, a history of } \\
\text { severe preeclampsia was independently associated with a } 3 \text {-fold higher risk of CVD. }\end{array}$ \\
\hline $\begin{array}{l}\text { Brown et al } \\
\text { GENOA study }\end{array}$ & 2013 & $\begin{array}{l}\text { A history of hypertension in pregnancy is associated with elevated CRP levels later in life, } \\
\text { independent of traditional CVD risk factors and BMI. }\end{array}$ \\
\hline Brown et al & 2013 & $\begin{array}{l}\text { Women diagnosed with history of preeclampsia were at increased risk of future CV or cere- } \\
\text { brovascular events, with an estimated doubling of odds compared with unaffected women. }\end{array}$ \\
\hline Melchiorre et al & 2014 & $\begin{array}{l}\text { The relative risk of developing hypertension within } 2 \text { y of birth, even after adjusting for } \\
\text { confounding risk factors, was increased } 15 \text {-fold if LV abnormalities persisted. The higher } \\
\text { prevalence of stage B heart failure in preterm than in term preeclampsia had a higher } \\
\text { risk of subsequent congestive heart failure and ischemic cardiac diseases compared with } \\
\text { women with term preeclampsia or normal pregnancy }\end{array}$ \\
\hline Veerbeek et al & 2015 & $\begin{array}{l}\text { Compared with women with late-onset preeclampsia and pregnancy-induced hyperten- } \\
\text { sion, women with previous early-onset preeclampsia had significantly higher fasting blood } \\
\text { glucose }(5.29 \text { vs. } 4.80 \text { and } 4.83 \mathrm{mmol} / \mathrm{L}) \text {, insulin ( } 9.12 \mathrm{vs.} 6.31 \text { and } 6.7 \mathrm{IU} / \mathrm{L}) \text {, triglycerides } \\
\text { (1.32 vs. } 1.02 \text { and } 0.97 \mathrm{mmol} / \mathrm{L}) \text {, and total cholesterol (5.14 vs. } 4.73 \text { and } 4.73 \mathrm{mmol} / \mathrm{L}) \text {. } \\
\text { Almost one-half of women with early-onset preeclampsia developed hypertension, as } \\
\text { opposed to } 39 \% \text { and } 25 \% \text { of women in the pregnancy-induced hypertension and late-onset } \\
\text { preeclampsia groups, respectively. }\end{array}$ \\
\hline Weissgerber et al & 2016 & $\begin{array}{l}\text { A sibling history of hypertension in pregnancy was also associated with an increased risk } \\
\text { of hypertension in brothers and unaffected sisters, whereas an increased risk of CV events } \\
\text { was observed in brothers only. These results suggested that familial factors contribute to } \\
\text { the increased risk of future hypertension in women who had hypertension in pregnancy. }\end{array}$ \\
\hline
\end{tabular}

Abbreviations: BMI, body mass index; CRP, C-reactive protein; CV, cardiovascular; CVD, cardiovascular disease; GENOA, Genetic Epidemiology Network of Arteriopathy; LV, left ventricular.

Table 3 Studies showing the increase in cardiovascular risk in preeclamptic women

\begin{tabular}{|l|l|l|}
\hline Study & Year & Results \\
\hline Stekkinger et al & 2009 & $\begin{array}{l}\text { The metabolic syndrome was present in 15-25\% of women after early-onset } \\
\text { vascular-complicated pregnancy and in 10-14\% of women after late-onset disease. }\end{array}$ \\
\hline Kessous et al & 2015 & $\begin{array}{l}\text { Patients with preeclampsia had significantly higher cumulative incidence of } \\
\text { atherosclerotic-related hospitalizations and had an increased risk of cardiomyopathy } \\
\text { during the peripartum period }\end{array}$ \\
\hline Behrens et al & 2016 & $\begin{array}{l}\text { Women with a history of hypertensive disorders of pregnancy had significantly increased } \\
\text { rates of cardiomyopathy. These increases persisted > 5 y after the latest pregnancy. }\end{array}$ \\
\hline Black et al & 2016 & $\begin{array}{l}\text { 2.36 and 2.48 times as likely, respectively, to develop pre-HTN/HTN (hypertension) in the } \\
\text { year after delivery as those without pregnancy-related HTN. History of preeclampsia is } \\
\text { also associated with an increased risk of future metabolic syndrome. }\end{array}$ \\
\hline
\end{tabular}

Table 4 Studies showing the increase in late other organ system disorders morbidity in preeclamptic women

\begin{tabular}{|l|l|l|}
\hline Study & Year & Results \\
\hline Aukes et al & 2012 & $\begin{array}{l}\text { History of preeclampsia was a risk marker for early cerebrovascular damage. They noted that } \\
\text { formerly eclamptic women demonstrate cerebral white matter lesions (WMLs) several years } \\
\text { following the index pregnancy. }\end{array}$ \\
\hline Weigman et al & 2012 & $\begin{array}{l}\text { Vision-related quality of life (QOL): Composite scores were significantly lower in formerly } \\
\text { eclamptic women than in control participants ( }<\text { < 0.01 for composite scores). }\end{array}$ \\
\hline Beharier et al & 2016 & $\begin{array}{l}\text { Women who had preeclampsia had a significantly higher incidence of long-term ophthalmic } \\
\text { morbidity such as diabetic retinopathy and retinal detachment. In addition, a positive linear } \\
\text { correlation was found between the severity of preeclampsia and the prevalence of future } \\
\text { ophthalmic morbidities (0.3 vs. 0.5 vs. 2.2\%, respectively). }\end{array}$ \\
\hline Postma et al & 2016 & $\begin{array}{l}\text { Formerly preeclamptic women reported cognitive dysfunction but did not exhibit overt } \\
\text { cognitive impairment when objectively tested on average 6 y following their pregnancy. The } \\
\text { presence of WML was not related to objective or to subjective cognitive impairment, anxiety, } \\
\text { and depressive symptoms. }\end{array}$ \\
\hline
\end{tabular}


Table 5 Studies showing the increase in late cardiovascular morbidity in premature deliveries in women

\begin{tabular}{|c|c|c|}
\hline Study author & Year & Results \\
\hline Kessous et al & 2013 & $\begin{array}{l}\text { A linear association was found between the number of previous preterm delivery (PTD) and } \\
\text { future risk of cardiovascular hospitalizations ( } 5.5 \% \text { for } \geq 2 \text { PTDs; } 5 \% \text { for } 1 \text { PTD vs. } 3.5 \% \text { in the } \\
\text { control group; } p<0.001) \text {. The association remained significant for spontaneous vs. induced } \\
\text { PTD and for early }(<34 \text { wk) and late ( } 34 \text { wk to } 36 \text { wk } 6 \text { days' gestation) PTD. }\end{array}$ \\
\hline Robbins et al & 2014 & $\begin{array}{l}\text { Compared with women who had term deliveries, women with any history of PTB had } \\
\text { increased risk of cardiovascular disease (CVD) morbidity (variously defined; adjusted hazard } \\
\text { ratio [aHR] ranged from 1.2-2.9), ischemic heart disease (aHR, 1.3-2.1), stroke (aHR, 1.7), } \\
\text { and atherosclerosis (aHR, 4.1). }\end{array}$ \\
\hline Ngo et al & 2015 & $\begin{array}{l}\text { aHR of CVD among women who ever had a preterm birth was } 1.78(1.61-1.96) \text {. Associations } \\
\text { were greater for extreme }(\mathrm{aHR}=1.98[1.63-2.42]) \text { and moderate }(\mathrm{aHR}=2.06[1.69-2.51]) \\
\text { than late preterm birth }(\mathrm{aHR}=1.63[1.44-1.85]) \text {, for indicated }(\mathrm{aHR}=2.04[1.75-2.38]) \\
\text { than spontaneous preterm birth }(\mathrm{aHR}=1.65[1.47-1.86]) \text {, and for having } \geq 2(\mathrm{aHR}=2.29 \\
[1.75-2.99]) \text { than having } 1 \text { preterm birth }(\mathrm{aHR}=1.73[1.57-1.92]) \text {. }\end{array}$ \\
\hline Catov et al & 2016 & $\begin{array}{l}\text { The relative hazard (95\% confidence interval }[\mathrm{CI}]) \text { for metabolic syndrome was } 1.52 \\
(1.22-1.88) \text { for women with preterm compared with term births. }\end{array}$ \\
\hline Almasi et al & 2016 & $\begin{array}{l}\text { Women with either spontaneous or indicated PTD had higher rates of renal-related } \\
\text { hospitalizations }(0.2 \% \text { vs. } 0.1 \% \text {; odds ratio }[\mathrm{OR}]=2.6 ; 95 \% \mathrm{Cl}: 1.7-3.9 ; p<0.001 \text { and } 0.5 \% \text { vs. } \\
0.2 \% \text {; OR }=3.41 ; 95 \% \mathrm{Cl}: 1.7-6.5 ; p<0.001 \text {, respectively). }\end{array}$ \\
\hline
\end{tabular}

Table 6 Studies showing the increase in late cardiovascular morbidity in placental abruption in women

\begin{tabular}{|l|l|l|}
\hline Study author & Year & Results \\
\hline Pariente et al & 2014 & $\begin{array}{l}\text { Compared with 46,932 women who delivered during the same period, the } \\
\text { cardiovascular case fatality rate for the placental abruption group was 13.0\% vs. 2.5\% } \\
(p<0.001) \text {. Placental abruption remained an independent risk factor for long-term } \\
\text { maternal cardiovascular mortality (adjusted hazard ratio (HR) }=4.3 ; 95 \% \text { confidence } \\
\text { interval [CI]: 1.1, 18.6). }\end{array}$ \\
\hline Arazi et al & 2015 & $\begin{array}{l}\text { Placental abruption, even though considered a part of the "placental syndrome" with } \\
\text { possible vascular etiology, was not found to be a risk factor for long-term maternal renal } \\
\text { complications. }\end{array}$ \\
\hline DeRoo et al & $\begin{array}{l}\text { Women with placental abruption in first pregnancy had an increased risk of } \\
\text { cardiovascular death CVD death (HR ratio 1.8; 95\% Cl: 1.3, 2.4). Results were essentially } \\
\text { unchanged by excluding women with pregestational hypertension, preeclampsia, } \\
\text { or diabetes. Women with placental abruption in any pregnancy also had a 1.8-fold } \\
\text { increased risk of CVD mortality (95\% Cl: 1.5, 2.2) compared with women who never } \\
\text { experienced the condition. }\end{array}$ \\
\hline Ananth et al & $\begin{array}{l}\text { CVD mortality rates in women with and without abruption were 0.9 and 0.3 per 10,000 } \\
\text { person-years, respectively (adjusted HR 2.7, 95\% Cl: 1.5, 5.0). The corresponding CVD } \\
\text { morbidity complication rates were 16.7 and 10.0 per 10,000 person-years, respectively } \\
\text { (HR 1.5, 95\% Cl: 1.4, 1.8). }\end{array}$ \\
\hline
\end{tabular}

Table 7 Studies showing the increase in late cardiovascular morbidity in still birth and recurrent miscarriages in women

\begin{tabular}{|l|l|l|}
\hline Study author & Year & Results \\
\hline Pariente et al & 2014 & $\begin{array}{l}\text { After stillbirth, women had a significantly higher cumulative incidence of cardiovascular and } \\
\text { renal morbidity and cardiovascular and renal hospitalizations, and had higher rates of simple } \\
\text { and complex cardiovascular events. A significant stepwise increase was found between the } \\
\text { number of stillbirths and future risk for cardiovascular morbidity. }\end{array}$ \\
\hline Kessous et al & 2014 & $\begin{array}{l}\text { Women with a history of recurrent pregnancy loss (RPL) had higher rates of renal and } \\
\text { cardiovascular morbidity. Using a Cox proportional hazards model, adjusted for confounders } \\
\text { such as preeclampsia, diabetes mellitus, obesity, and smoking, a history of RPL remained } \\
\text { independently associated with cardiovascular hospitalizations. }\end{array}$ \\
\hline
\end{tabular}


Table 8 Long-term risks for mother following complicated pregnancy

\begin{tabular}{|c|c|c|c|c|c|c|c|}
\hline $\begin{array}{l}\text { Type of } \\
\text { abnormality }\end{array}$ & $\begin{array}{l}\text { Cardiac (HF + CAD } \\
\text { - microvascular } \\
\text { dysfunction, } \\
\text { obstructive lesions, } \\
\text { AMI, coronary } \\
\text { calcification) }\end{array}$ & Thromboembolic & Ophthalmology & Renal & Stroke & $\begin{array}{l}\text { Cor } \\
\text { pulmonale }\end{array}$ & $\begin{array}{l}\text { Others } \\
\text { (cancer) }\end{array}$ \\
\hline GDM & Yes & No & No & No & Yes & No & No \\
\hline Preeclampsia & Yes & Yes & No & No & Yes & No & No \\
\hline $\begin{array}{l}\text { Preterm } \\
\text { deliveries }\end{array}$ & Yes & No & No & Yes & Yes & No & No \\
\hline $\begin{array}{l}\text { Abruption } \\
\text { placenta }\end{array}$ & Yes & No & No & No & No & No & No \\
\hline $\begin{array}{l}\text { Maternal } \\
\text { obesity }\end{array}$ & No & No & Yes & No & No & No & No \\
\hline $\begin{array}{l}\text { Women with } \\
\text { SGA neonates }\end{array}$ & Yes & No & No & Yes & No & Yes & No \\
\hline $\begin{array}{l}\text { Preeclampsia } \\
\text { and eclampsia }\end{array}$ & Yes & Yes & No & Yes & Yes & No & No \\
\hline
\end{tabular}

Abbreviations: AMI, acute myocardial infarction; CAD, coronary artery disease; GDM, gestational diabetes mellitus; HF, heart failure; SGA, small for gestational age.

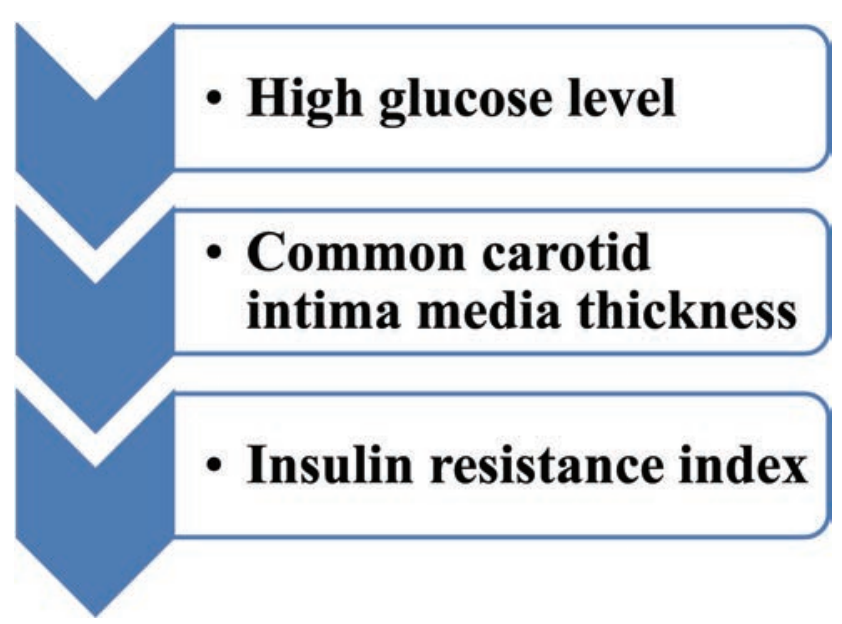

Fig. 1 Markers in GDM patients to detect the CVD subsequently. 


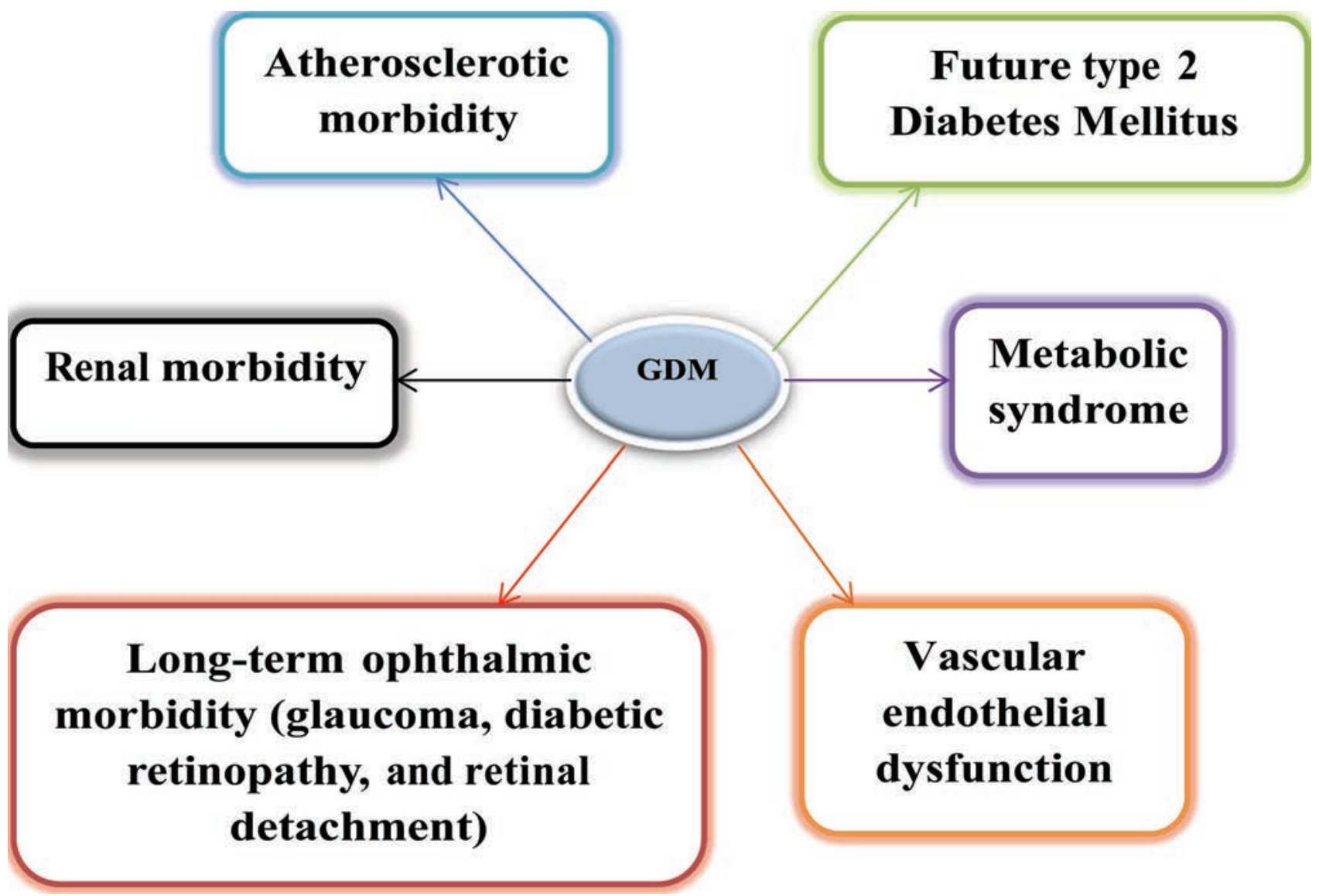

Fig. 2 GDM-future events. 


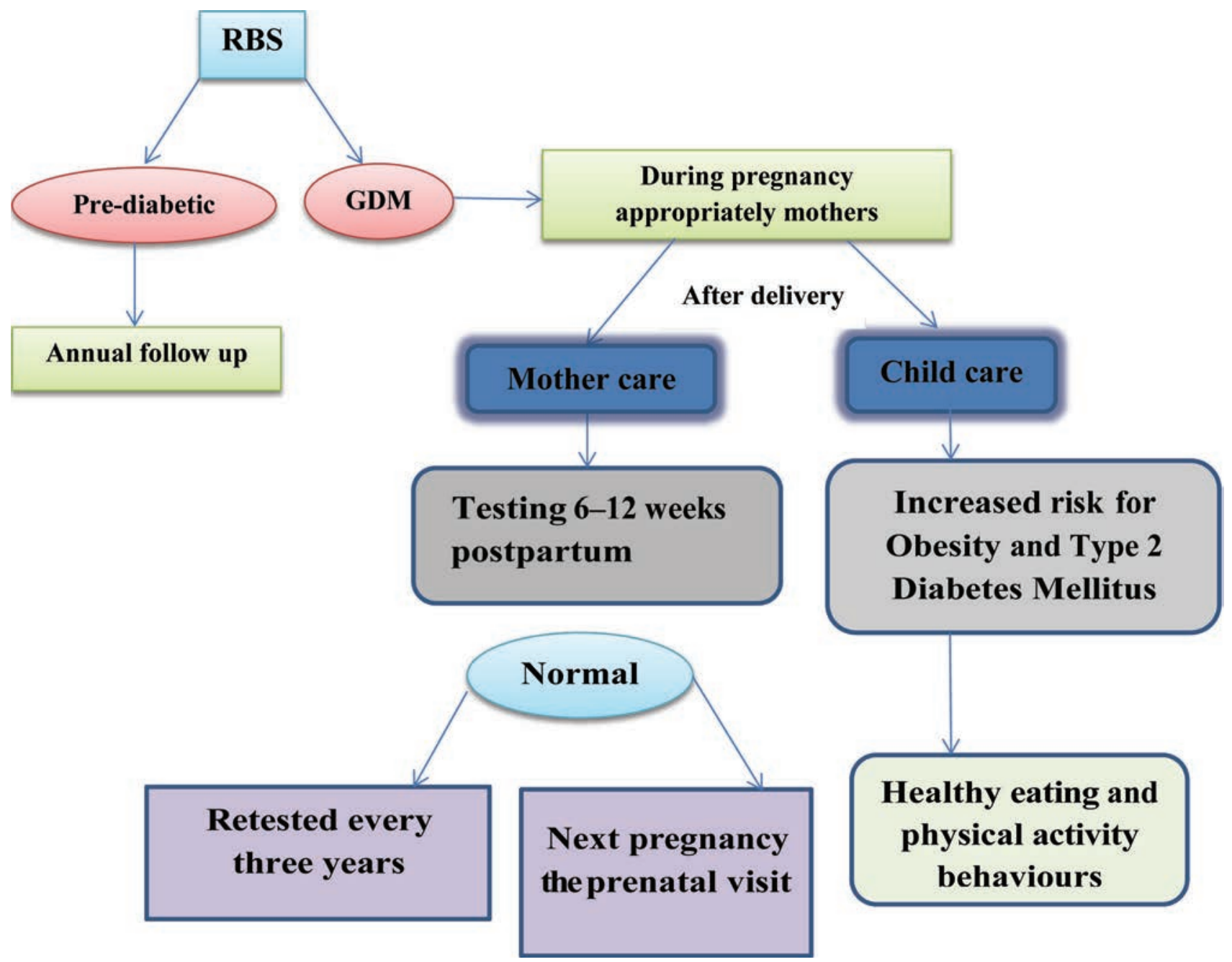

Fig. 3 Follow-up of GDM patient (ACOG and the American Diabetes Association recommend testing women recommendation). 


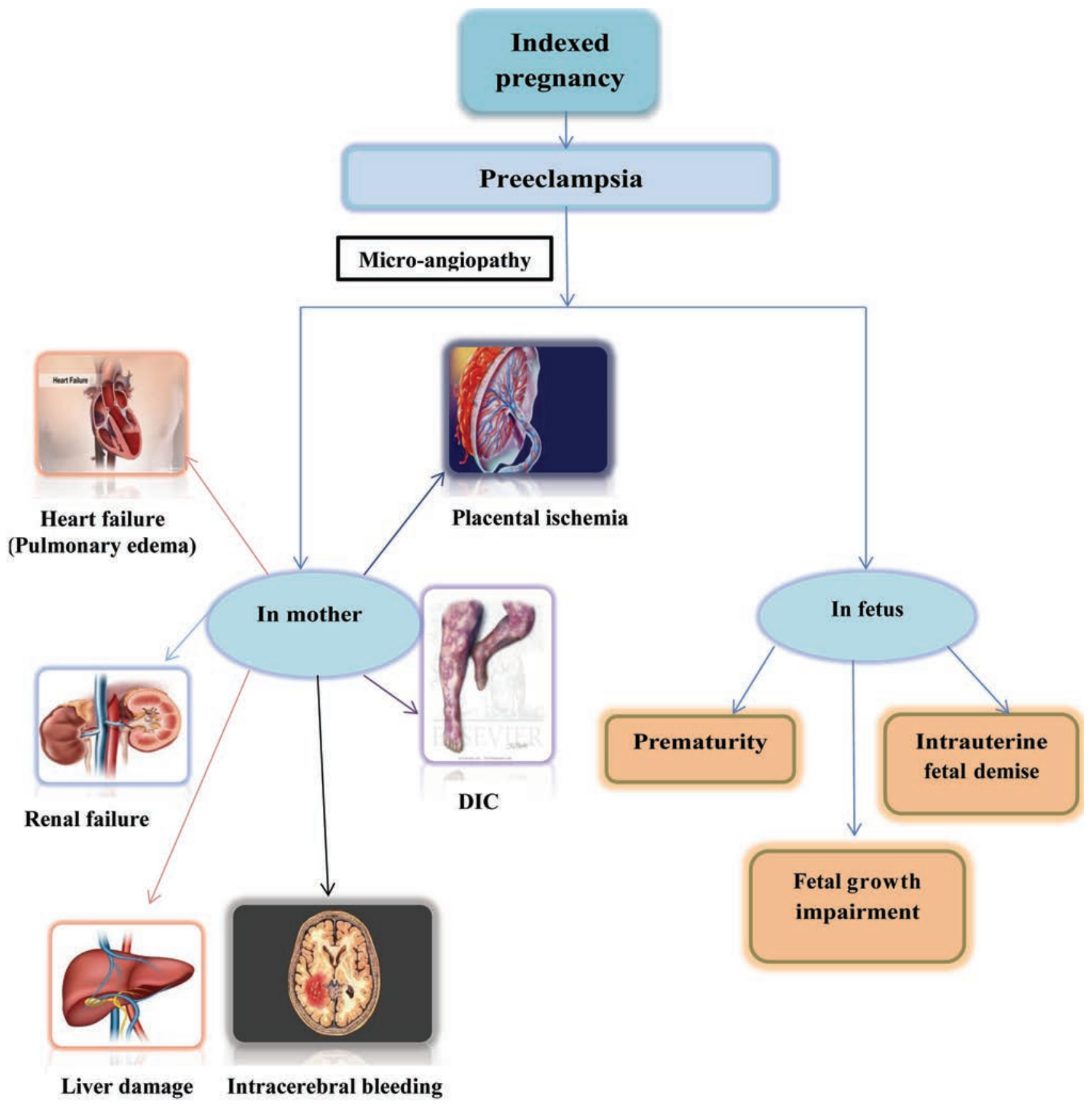

Fig. 4 Effects of preeclampsia during indexed pregnancy. 


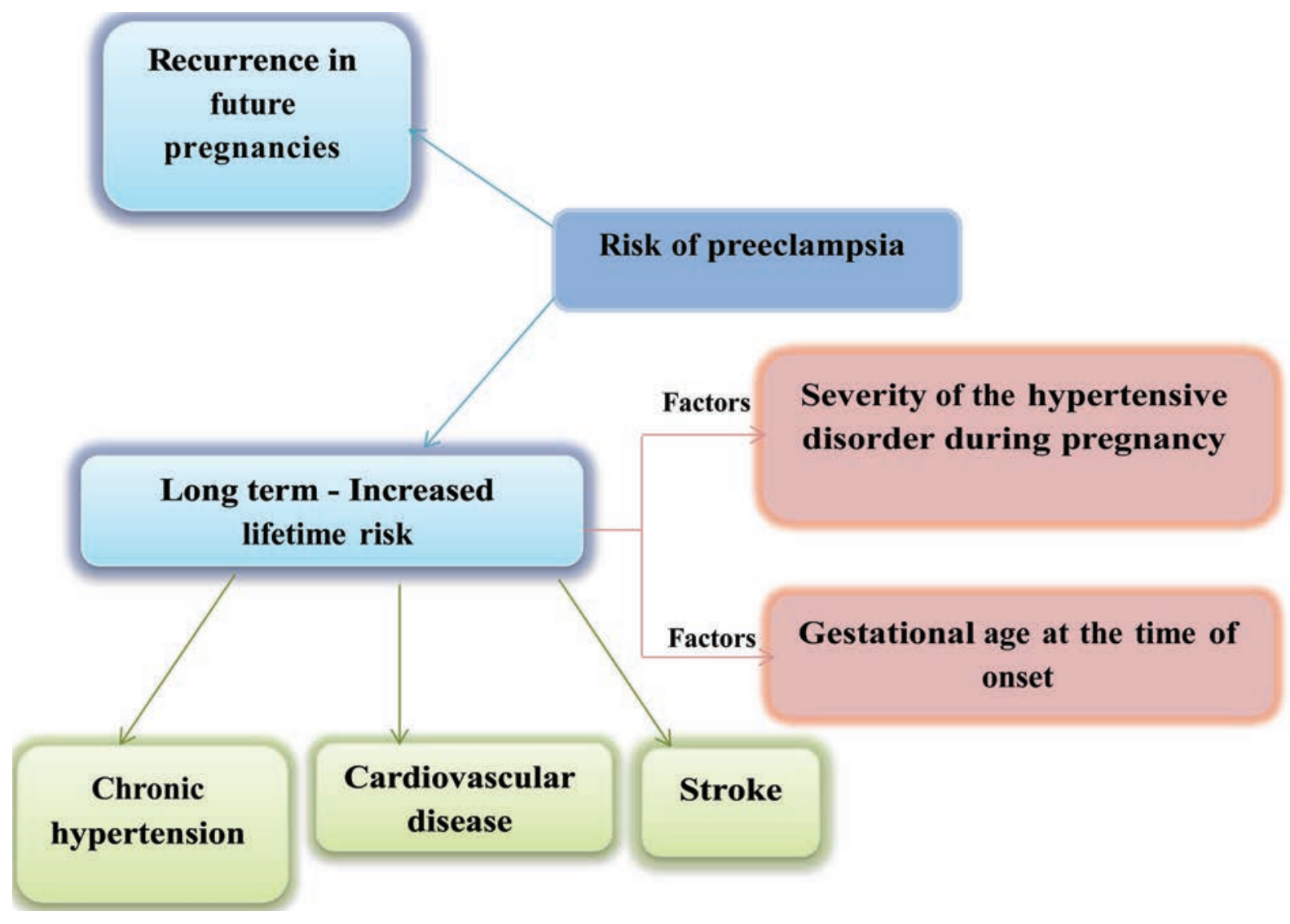

Fig. 5 Risk of preeclampsia.

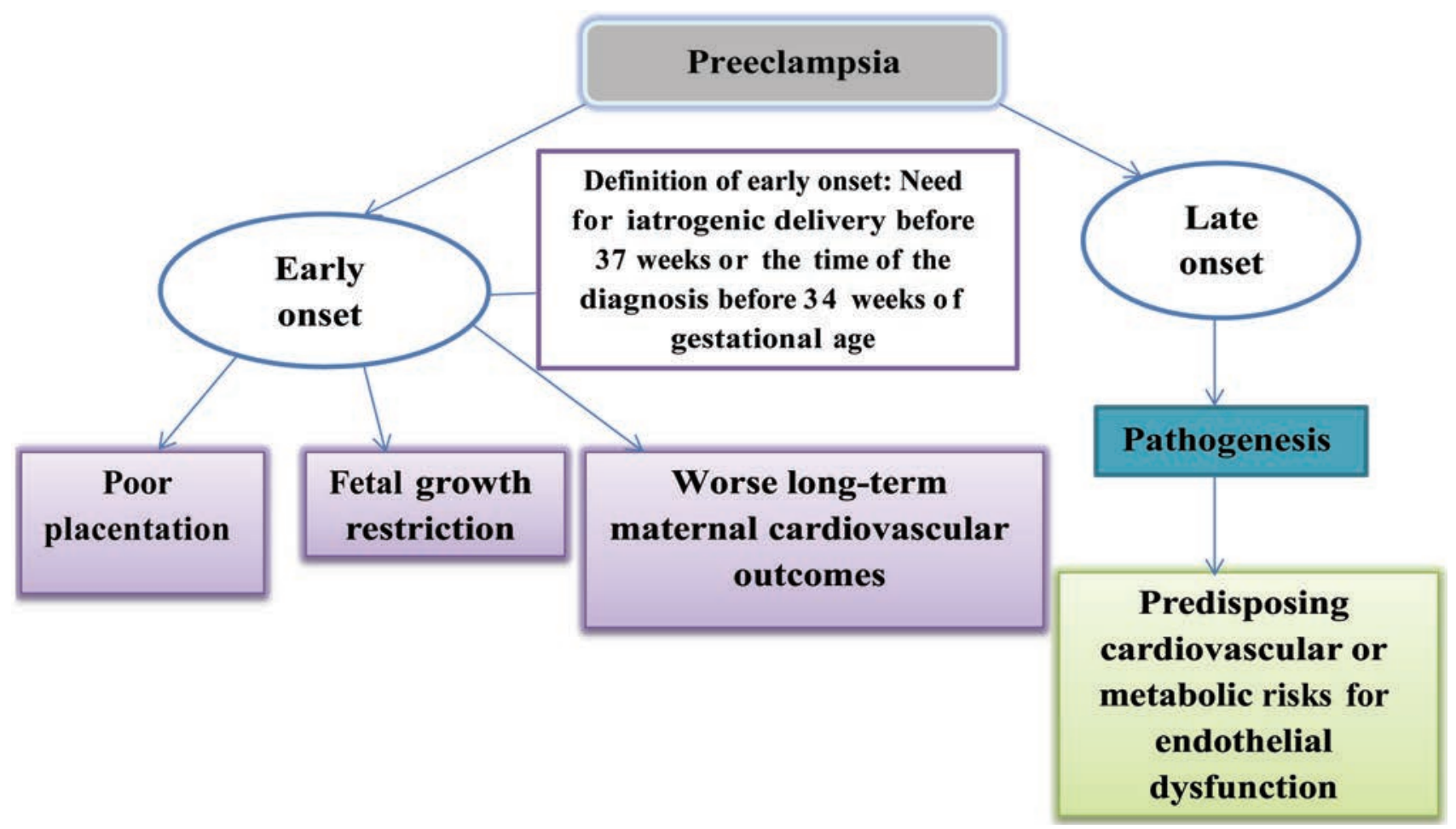

Fig. 6 Gestational age at the time of occurrence of preeclampsia. 


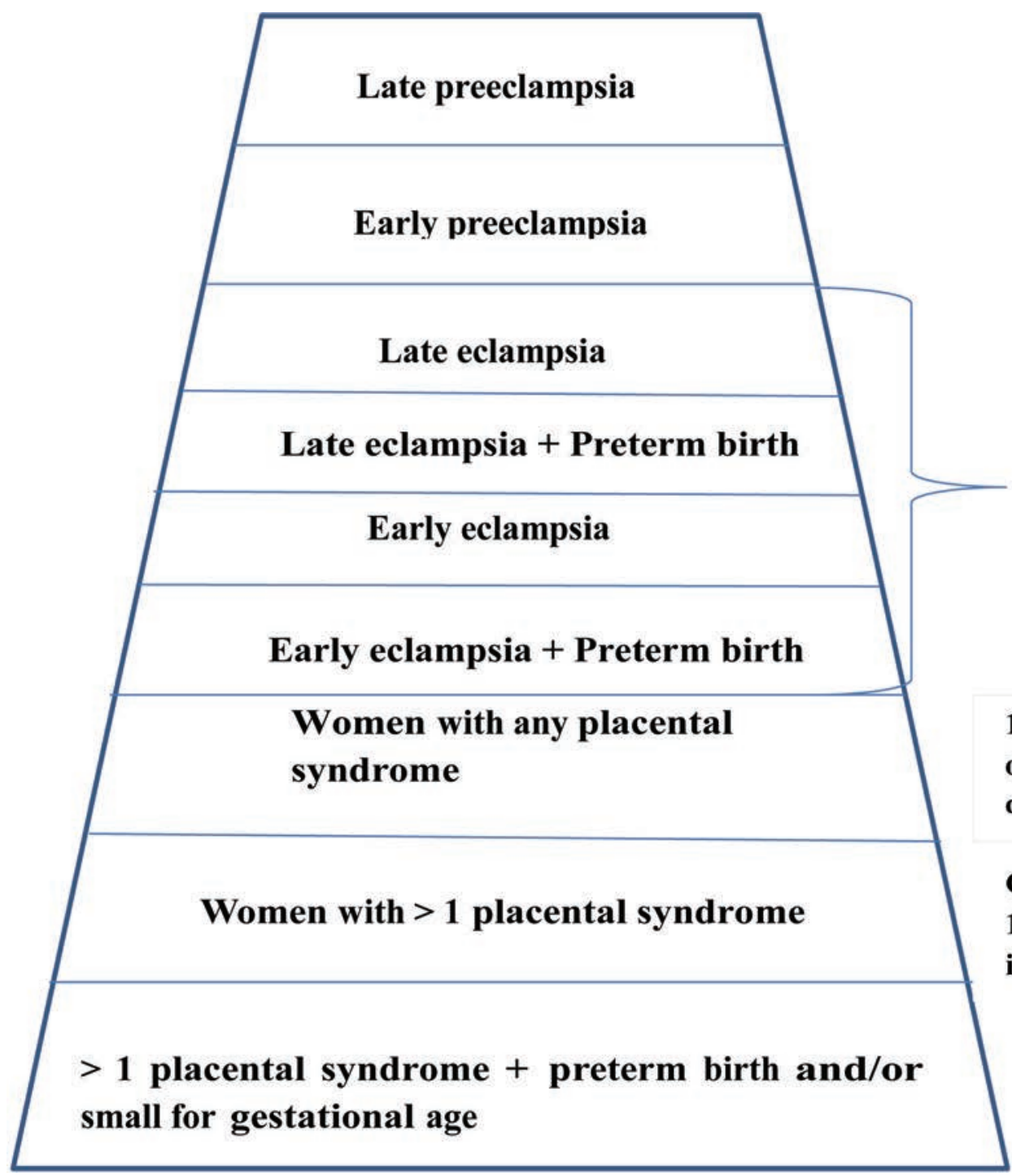

Hazard ratio, 1.42;

$\mathbf{9 5} \%$ confidence

interval, (1.14-1.76)

$19 \%$ increased risk of cardiovascular disease

CVD risk (hazard ratio, $1.43 ; 95 \%$ confidence interval, 1.20-1.70)

Risk of cardiovascular disease increased $45 \%$.

Fig. 7 Pyramid of relative risk of different stages of eclampsia for future cardiovascular disease.

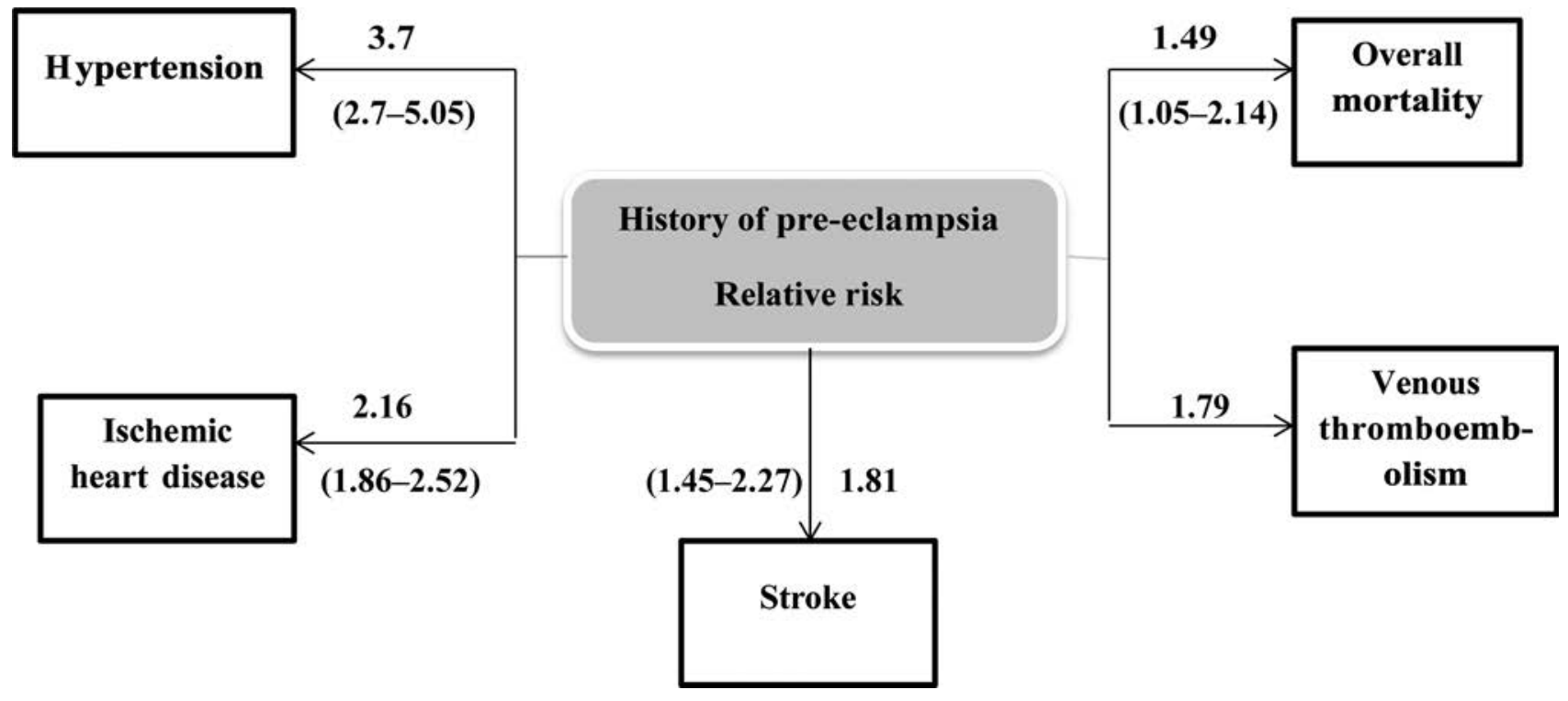

Fig. 8 Preeclampsia-subsequent cardiovascular disease. 


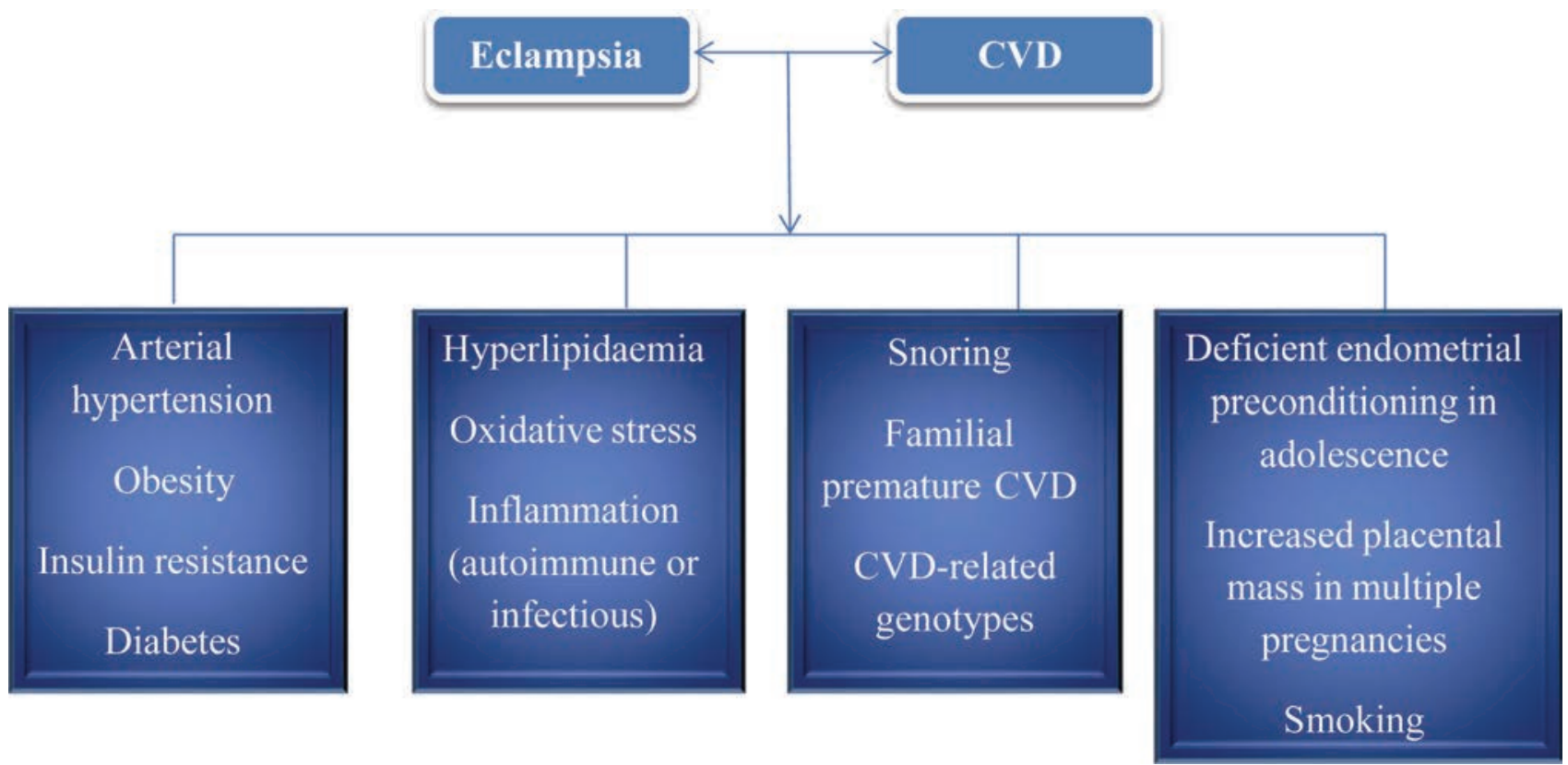

Fig. 9 Common factors for eclampsia and CVD. 


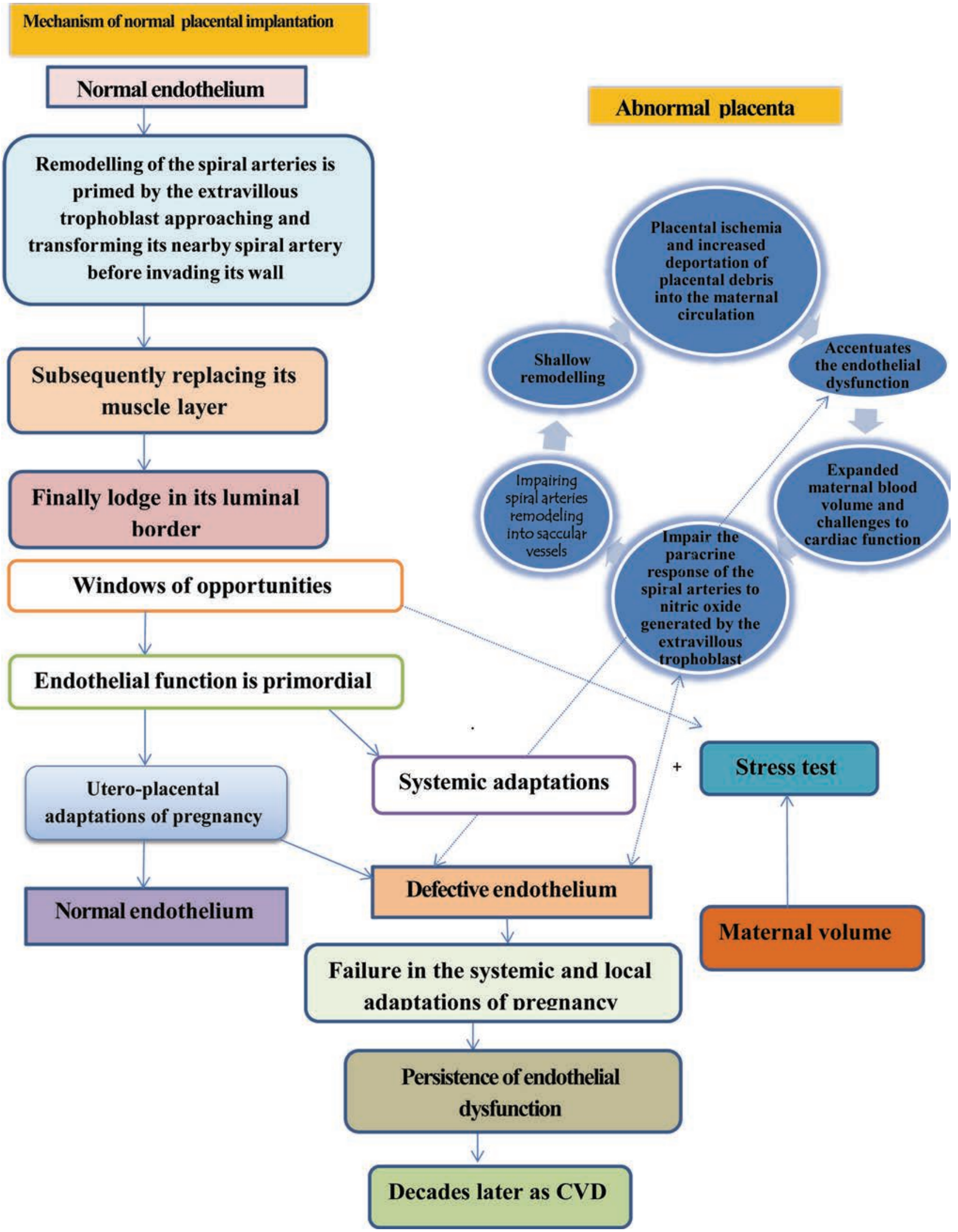

Fig. 10 Pathophysiology of complicated pregnancy leading to long-term maternal effects. 


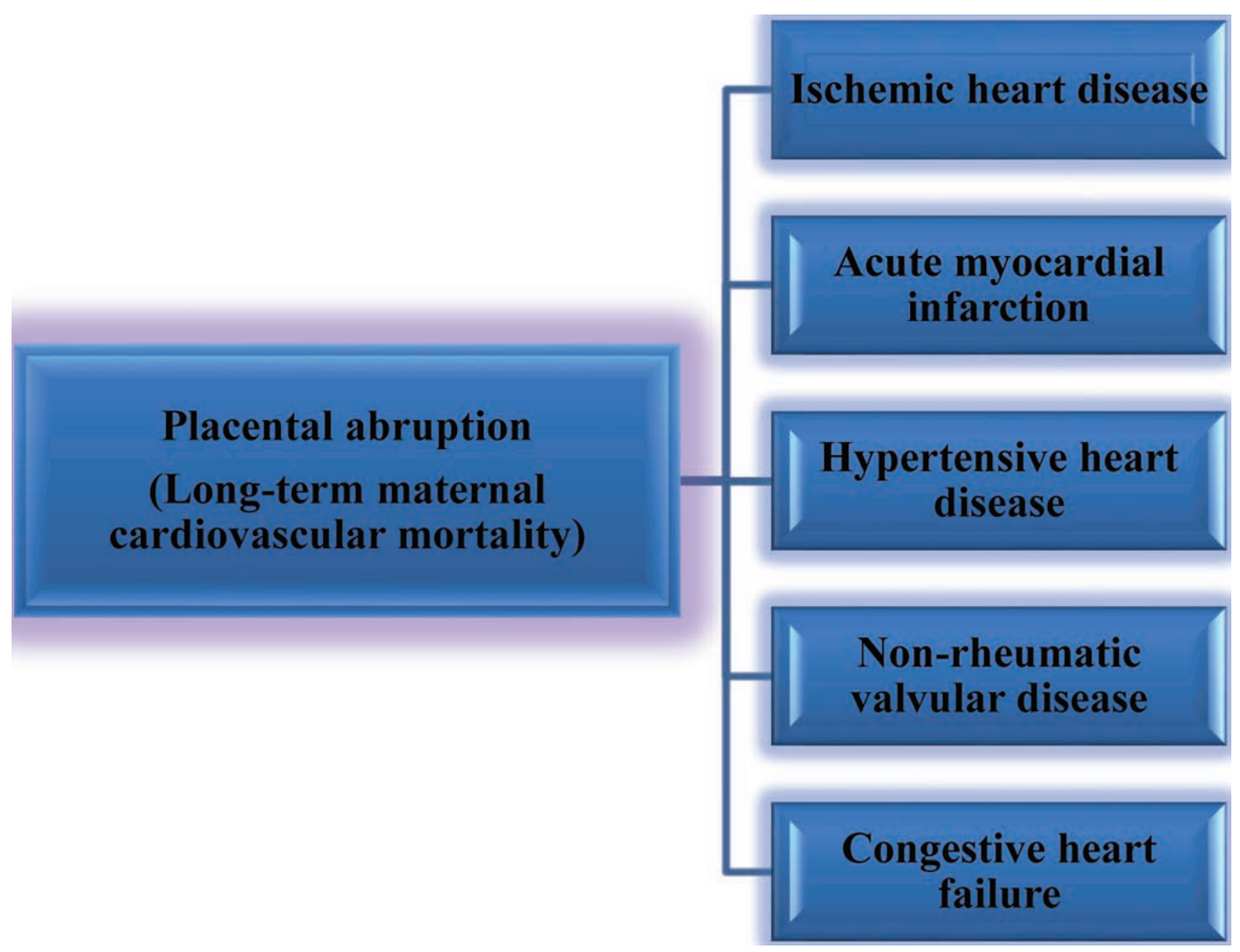

Fig. 11 Placental abruption-subsequent cardiovascular disease. 


\section{Diet modifications}

\section{Weight loss}

\section{Increased physical activity}

\section{Encouraged to breastfeed}

\section{Dancing}

\section{Correction of CVR (cardiovascular risks)}

\section{Aspirin, Ca L-arginine, Pravastatin (for defective placental adaptation)}

Fig. 12 Recommendations for prevention of long-term risk for mother.

\section{References}

1 Neiger R, Grant-Kel J. Long-term effects of pregnancy complications on maternal health: a review. J Clin Med 2017;6(8):76

2 Pariente G, Kessous R, Sergienko R, Sheiner E. Is preterm delivery an independent risk factor for long-term maternal kidney disease? J Matern Fetal Neonatal Med 2017;30:1102-1107
3 Almasi O, Pariente G, Kessous R, Sergienko R, Sheiner E. Association between delivery of small-for-gestational-age neonate and long-term maternal chronic kidney disease. J Matern Fetal Neonatal Med 2016;29:2861-2864

4 Sattar N, Greer IA. Pregnancy complications and maternal cardiovascular risk: opportunities for intervention and screening? BMJ 2002;325:157-160 
5 Lee M, Saver JL, Hong KS, Song S, Chang KH, Ovbiagele B. Effect of pre-diabetes on future risk of stroke: meta analysis. BMJ 2012;344(3):564

6 Huang Y, Cai X, Mai W, Li M, Hu Y. Association between prediabetes and risk of cardiovascular disease and all cause mortality: systematic review and meta-analysis. BMJ 2016;355(5):953

7 Bellamy L, Casas JP, Hingorani AD, Williams D. Type 2 diabetes mellitus after gestational diabetes: a systematic review and meta-analysis. Lancet 2009;373:1773-1779

8 Göbl CS, Bozkurt L, Prikoszovich T, Winzer C, Pacini G, Kautzky-Willer A. Early possible risk factors for overt diabetes after gestational diabetes mellitus. Obstet Gynecol 2011;118:71-78

9 Lauenborg J, Mathiesen E, Hansen T, et al. The prevalence of the metabolic syndrome in a Danish population of women with previous gestational diabetes mellitus is three-fold higher than in the general population. J Clin Endocrinol Metab 2005;90:4004-4010

10 Valizadeh M, Alavi N, Mazloomzadeh S, Piri Z, Amirmoghadami $\mathrm{H}$. The risk factors and incidence of type 2 diabetes mellitus and metabolic syndrome in women with previous gestational diabetes. Int J Endocrinol Metab 2015;13(2):1696

11 Kessous R, Shoham-Vardi I, Pariente G, Sherf M, Sheiner E. An association between gestational diabetes mellitus and long-term maternal cardiovascular morbidity. Heart 2013;99:1118-1121

12 Gabbe SG, Landon MB, Warren-Boulton E, Fradkin J. Promoting health after gestational diabetes: a National Diabetes Education Program call to action. Obstet Gynecol 2012;119:171-176

13 Bokslag A, Teunissen PW, Franssen C, et al. Effect of earlyonset preeclampsia on cardiovascular risk in the fifth decade of life. Am J Obstet Gynecol 2017;216(5):523.e1-523.e7

14 Irgens HU, Reisaeter L, Irgens LM, Lie RT. Long term mortality of mothers and fathers after preeclampsia: population based cohort study. BMJ 2001;323:1213-1217

15 McDonald SD, Yusuf S, Walsh MW, et al. Increased cardiovascular risk after preeclampsia in women with dysglycaemia. Diabet Med 2013;30:e1-e7

16 Brown CM, Turner ST, Bailey KR, et al. Hypertension in pregnancy is associated with elevated C-reactive protein levels later in life. J Hypertens 2013;31:2213-2219

17 Weissgerber TL, Turner ST, Mosley TH Jr, et al. Hypertension in pregnancy and future cardiovascular event risk in siblings. J Am Soc Nephrol 2016;27:894-902

18 Brown MC, Best KE, Pearce MS, Waugh J, Robson SC, Bell R. Cardiovascular disease risk in women with preeclampsia: systematic review and meta-analysis. Eur J Epidemiol 2013;28:1-19

19 Melchiorre K, Sharma R, Thilaganathan B. Cardiovascular implications in preeclampsia: an overview. Circulation 2014;130:703-714

20 Veerbeek JH, Hermes W, Breimer AY, et al. Cardiovascular disease risk factors after early-onset preeclampsia, late-onset preeclampsia, and pregnancy-induced hypertension. Hypertension 2015;65:600-606

21 White WM, Mielke MM, Araoz PA, et al. A history of preeclampsia is associated with a risk for coronary calcification 3 years later. Am J Obstet Gynecol 2016;214(4):519.e1-519.e8

22 Valdés G, Quezada F, Marchant E, et al. Association of remote hypertension in pregnancy with coronary artery disease: a case-control study. Hypertension 2009;53(4):733-738

23 Henriques AC, Carvalho FH, Feitosa HN, Macena RH, Mota RM, Alencar JC. Endothelial dysfunction after pregnancy-induced hypertension. Int J Gynaecol Obstet 2014;124(3):230-234

24 Kessous R, Shoham-Vardi I, Pariente G, Sergienko R, Sheiner E. Long-term maternal atherosclerotic morbidity in women with preeclampsia. Heart 2015;101:442-446
25 Behrens I, Basit S, Lykke JA, et al. Association between hypertensive disorders of pregnancy and later risk of cardiomyopathy. JAMA 2016;315:1026-1033

26 Black MH, Zhou H, Sacks DA, et al. Hypertensive disorders first identified in pregnancy increase risk for incident prehypertension and hypertension in the year after delivery. J Hypertens 2016;34:728-735

27 Stekkinger E, Zandstra M, Peeters LL, Spaanderman ME. Early-onset preeclampsia and the prevalence of postpartum metabolic syndrome. Obstet Gynecol 2009;114:1076-1084

28 Aukes AM, De Groot JC, Wiegman MJ, Aarnoudse JG, Sanwikarja GS, Zeeman GG. Long-term cerebral imaging after preeclampsia. BJOG 2012;119:1117-1122

29 Wiegman MJ, de Groot JC, Jansonius NM, Aarnoudse JG, Groen H, Faas Zeeman GG. Long-term visual functioning after eclampsia. Obstet Gynecol 2012;119:959-966

30 Beharier O, Davidson E, Sergienko R, et al. Preeclampsia and future risk for maternal ophthalmic complications. Am J Perinatol 2016;33:703-707

31 Postma IR, Bouma A, de Groot JC, Aukes AM, Aarnoudse JG, Zeeman GG. Cerebral white matter lesions, subjective cognitive failures, and objective neurocognitive functioning: a follow-up study in women after hypertensive disorders of pregnancy. J Clin Exp Neuropsychol 2016;38:585-598

32 Valdés G. Preeclampsia and cardiovascular disease: interconnected paths that enable detection of the subclinical stages of obstetric and cardiovascular diseases [review]. Integr Blood Press Control 2017;10:17-23

33 Kessous R, Shoham-Vardi I, Pariente G, Holcberg G, Sheiner E. An association between preterm delivery and long-term maternal cardiovascular morbidity. Am J Obstet Gynecol 2013;209:368.e1-368.e8

34 Robbins CL, Hutchings Y, Dietz PM, Kuklina EV, Callaghan WM. History of preterm birth and subsequent cardiovascular disease: a systematic review. Am J Obstet Gynecol 2014;210:285-297

35 Ngo AD, Chen JS, Figtree G, Morris JM, Roberts CL. Preterm birth and future risk of maternal cardiovascular disease-is the association independent of smoking during pregnancy? BMC Pregnancy Childbirth 2015;15:144

36 Catov JM, Althouse AD, Lewis CE, Harville EW, Gunderson EP. Preterm delivery and metabolic syndrome in women followed from prepregnancy through 25 years later. Obstet Gynecol 2016;127:1127-1134

37 Pariente G, Shoham-Vardi I, Kessous R, Sherf M, Sheiner E. Placental abruption as a significant risk factor for long-term cardiovascular mortality in a follow-up period of more than a decade. Paediatr Perinat Epidemiol 2014;28:32-38

38 DeRoo L, Skjærven R, Wilcox A, et al. Placental abruption and long-term maternal cardiovascular disease mortality: a population-based registry study in Norway and Sweden. Eur J Epidemiol 2016;31:501-511

39 Ananth CV, Hansen AV, Williams MA, Nybo Andersen AM. Cardiovascular disease in relation to placental abruption: a population-based cohort study from Denmark. Paediatr Perinat Epidemiol 2017;31:209-218

40 Arazi ES, Kessous R, Shoham-Vardi I, Pariente G, Sergienko R, Sheiner E. Is there an association between a history of placental abruption and long-term maternal renal complications? J Matern Fetal Neonatal Med 2015;28:1641-1646

41 Pariente G, Shoham-Vardi I, Kessous R, Sergienko R, Sheiner E. Is stillbirth associated with long-term atherosclerotic morbidity? Am J Obstet Gynecol 2014;211:416.e1-416.e12

42 Kessous R, Shoham-Vardi I, Pariente G, Sergienko R, Holcberg $\mathrm{G}$, Sheiner E. Recurrent pregnancy loss: a risk factor for longterm maternal atherosclerotic morbidity? Am J Obstet Gynecol 2014;211:414.e1-414.e14 
43 Sasson I, Beharier O, Sergienko R, et al. Obesity during pregnancy and long-term risk for ophthalmic morbidity-a population-based study with a follow-up of more than a decade. J Matern Fetal Neonatal Med 2016;29:2924-2928

44 Wing RR, Espeland MA, Hazuda HP, et al; Action for Health in Diabetes (Look AHEAD) Study Group. Association of Weight Loss Maintenance and Weight Regain on 4-Year Changes in CVD Risk Factors: the Action for Health in Diabetes (Look AHEAD) Clinical Trial. Diabetes Care 2016;39:1345-1355

45 Pariente G, Sheiner E, Kessous R, Michael S, Shoham-Vardi I. Association between delivery of a small-for-gestational-age neonate and long-term maternal cardiovascular morbidity. Int J Gynaecol Obstet 2013;123:68-71

46 Bellamy L, Casas JP, Hingorani AD, Williams DJ. Preeclampsia and risk of cardiovascular disease and cancer in later life: systematic review and meta-analysis. BMJ 2007;335:974-978
47 Riise HK, Sulo G, Tell GS, et al. Incident coronary heart disease after preeclampsia: role of reduced fetal growth, preterm delivery, and parity. J Am Heart Assoc 2017;6(3):4158

48 Gongora MC, Wenger NK. Cardiovascular complications of pregnancy. Int J Mol Sci 2015;16:23905-23928

49 Heidrich MB, Wenzel D, von Kaisenberg CS, Schippert C, von Versen-Höynck FM. Preeclampsia and long-term risk of cardiovascular disease: what do obstetrician-gynecologists know? BMC Pregnancy Childbirth 2013;13:61

50 Regitz-Zagrosek V, Roos-Hesselink JW, Bauersachs J, et al. 2018 ESC guidelines for the management of cardiovascular diseases during pregnancy. Eur Heart J 2018;39(34): 3165-3241 